\title{
Development of Tourist Village Model Through "Pokdarwis" Empowerment and Information Technology Utilization
}

\author{
Syarif Hidayatullah $^{1} \quad$ Ike Kusdyah Rachmawati $^{2} \quad$ Umu Khouroh $^{1} \quad$ Irany Windhyastiti $^{*}$ \\ 1.Management Department, University of Merdeka Malang, Indonesia \\ 2.Management Department, Asia University, Indonesia
}

\begin{abstract}
Tourism sector is the one of the leading sectors of Batu City in Indonesia. To facilitate the achievement of the target of marketing Batu City in the international world, Government of Batu City can explore the natural attractions or the uniqueness of local tourism through the development of Rural Tourism. In early stage the development of Tourism Village in Batu City is done by forming Community Based Tourism called Pokdarwis. This research is a case study on Pokdarwis in Village of Pesanggrahan, Junrejo, Dadaprejo and Tulungrejo in Batu City. Analytical techniques used in this study is descriptive analysis. Based on the results of data analysis in three locations of tourism villages shows that Pokdarwis still has not played an effective role in tourism activities. Only one village is Tulungrejo Village whose Pokdarwis activities are visible. In general, Pokdarwis in three villages faced obstacles in the implementation of activities in terms of: 1) Pokdarwis members still lacked awareness about the importance and benefits of increasing tourism activities in the region, 2) Pokdarwis members still due independently marketing and promoting their personal business, not their region; 3) The Government of Tourism Department does not coordinate and assist them intensively. These three things, hampered the development of tourist villages. In fact in these three villages each has excellent potential that can be developed. Therefore, to improve the role of Pokdarwis it is suggest that the goverment must empower Pokdarwis trough : 1) conduct socialization and training to open the the community mind about the importance and benefits of tourism activities development in the region; 2) help choose a reliable leader; and 3) conduct intensive coordination and assistance. In general it can be concluded that the existence of Pokdarwis needs to be supported and nurtured continuously, so that it can play a more effective role in mobilizing public participation in creating conducive environment and atmosphere to improve and develop tourism activities around tourism destinations. In addition it also needs the introduction of information technology for Pokdarwis to promote the potential of their village.
\end{abstract}

Keywords: Pokdarwis, Community Based Tourism, Tourism Village, Empower, Information Technology

\section{Introduction}

Tourism sector is the one of the leading sectors of Batu City in Indonesia. Batu City known as Swiss Van Java. The number of tourists in Batu City in 2016 reached 4,2 million tourists. In 2016 local budget, Government of Batu City set a revenue target of IDR 1 trillion, which $80 \%$ comes from the tourism sector. Goverment of Batu City has a target to conjure Batu City into an international tourism destination. To achievement of these target, Government of Batu City can not rely solely on artificial tourism conducted by private parties such as Jatim Park Group, but also have to develop various nature tourism or other uniqueness of Batu City. The Government of Batu City can explore the natural attractions or the uniqueness of local tourism through the development of tourism village. Local communities play an important role in the development of tourism villages because the resources and uniqueness of traditions and cultures inherent in the community is the main driving element of tourism village activities. On the other hand, local communities that grow and co-exist with a tourism attraction become part of an interconnected ecological system. The success of developing a tourism villages depends on the level of acceptance and support of local communities (Wearing \& Donald, 2002). The local community acts as the host and becomes an important player in the development of the tourism village in all phases from the planning, supervision and implementation stage.

To support the development of tourism in Batu City, in early stage Tourism Department make a community called "Pokdarwis". Pokdarwis is implementation of Community Based Tourism (CBT) as an empowerment approach that involves and putting the community as an important player in the context of a new paradigm of development that is sustainable development (sustainable development paradigm). Community-based tourism is an opportunity to mobilize all the potential and dynamics of society, to offset the role of large-scale tourism business actors. In general, the development of tourism potential still places the community as an object not as a subject or an important player in tourism development. This caused many local people have not received the benefits of tourism development optimally and adequately. Therefore, in the development of tourism should make the empowerment of society as a modernization with a more complete supporting infrastructure (Muzha, Ribawanto, \& Hadi, 2013)

The formation of Pokdarwis is one of the marketing activities of City Branding namely people marketing. A tourism city can not only rely on promotions by local governments. The role of community support is need to 
create a conducive culture and climate to the develop of tourism in their area. Entrepreneurs, lodging, tour services, transportation rentals, merchants, hotels must all work together in advancing the region (Intyaswono, Yulianto, \& Mawardi, 2016). In addition it also needs the information technology to promote the tourism potential. Based on the above description, the purpose of this study is is to develop the model of tourist village through "pokdarwis" empowerment and information technology utilization.

\section{Theoretical Background \\ 2.1. Community Based Tourism (CBT)}

CBT is a tourism that realizes cultural, social, and environmental sustainability. This form of tourism is managed and owned by the community for the community, to help tourists increase their awareness and learn about the community and local way of life. Thus, CBT is very different from mass tourism. CBT is a model of tourism development that assumes tourism must depart from the awareness of community needs as an effort to build tourism that is more beneficial to the needs, initiatives and opportunities of local communities (Pinel, 1998). CBT is not a tourist business that aims to maximize profit for investors. CBT is more related to the impact of tourism for communities and environmental resources. CBT was born out of a community development strategy, uses tourism as a tool to strengthen the capacity of rural / local community organizations.

The concept of CBT has principles that can be used as a tool of community development for local communities, i.e: acknowledge, support and promote community-owned tourism, involve community members from the beginning on every aspect, promote community pride, improve quality of life, ensure environmental sustainability, maintaining unique local character and culture, help developing a cross-cultural learning, respect for cultural differences and human dignity, distributing benefits fairly among community members, and contributes a defined percentage of the community's project income.

\subsection{CBT Development Model}

Interest in public participation in the world of tourism begin in America in the early 1970s. Gunn campaigned the use of a joint forum that was attended by community leaders, constituents, tourism stakeholders as expected (Gunn, 1972). He believes that the benefits of the community approach. He advocates may be beneficial to the population anbegid visitors. Then the one who popularize the concept of community-based tourism development is (Murphy, 1985). He says that tourism products are locally articulated and consumed. Tourism products and consumers must be visible to locals who are often very aware of the impact of tourism. Therefore, tourism should involve local people, as part of tourism product, then industry should also involve local people in decision making. Because local communities have to bear the cumulative impact of tourism developments and they need to have greater input how communities are packaged and sold as tourism products (Murphy, 1985). Getz and Jamal criticize the Murphy model, because it does not offer blueprints to implement it in concrete form. Murphy concept in its implementation still have many problems (Getz \& Jamal, 1994). Public participation is seen as a tool for maintaining the integrity and authenticity as well as the competitive ability of tourism products However, when the public participation emerges, tourism destination planning remains focused on commercial interests and very little public engagement. The purpose of this model's tourism planning is more focused on preserving the uniqueness and attractiveness, and in fact more top-down, business-oriented, and economically oriented approach (Bahaire \& Elliot-White, 1999). The community approach model becomes the standard for tourism development process, which involves the community in it is a very important factor for the success of tourism products.

In the 1990s, along with the development of interest in developing sustainable tourism products, the form of community participation became very urgent. This form of community participation becomes essential for the achievement of sustainable tourism and for the realization of quality tourism. Getz and Jamal developed the theoretical foundations of community involvement in tourism planning and development and analyzed the nature and purpose of different collaboration models of cooperative models (Getz \& Jamal, 1994). They both define collaboration as "a process of joint decision-making among autonomous stakeholders of the interorganizational domain to solve problems or manage tourism-related issues. The collaboration process includes :1) Problem setting by identify key stakeholders and issues; 2) Direction Setting by share a collaborative interpretation, appreciating common goals; 3) Structuring and implementing,; 4) Institutionalization.

D'amore provides guidance models for the development of community-based tourism, i.e : identify development priorities by local residents (resident), promote and encourage local people, engaging local people in industry, investment in local capital or entrepreneurship is needed, participation of the population in events and extensive activities, tourism products to describe local identity, addressing problems that arise before further development. That points are summaries of the community approach. Local communities should be "involved", so they can not only enjoy the benefits of tourism and continue to support the development of tourism in which the community can provide lessons and explain in more detail the history and uniqueness. In order for CBT to work successfully, there are some elements of CBT that must be considered, namely: natural and cultural 
resources, community organizations, management and learning. The lesson here aims to help the learning process between Hosts and Guest, educate and build understanding between different ways of life and culture, raising awareness of cultural conservation and resources among tourists and the wider community (D'amore, 1983).

\subsection{Tourism Village}

Tourism village is a rural area that offers a whole atmosphere that reflects the authenticity of the countryside, both in terms of cultural social life, daily customs, architecture and spatial structure of the village and has the potential for the development of various components of tourism such as attractions, souvenirs, and other tourist needs. (Ministry Of Culture and Tourism, 2001). The countryside with its uniqueness, such as the natural environment, the beautiful landscapes, the diverse plants, the rural communities and their distinctive lifestyle, is an alternative to providing 'other' experiences to tourists and at the same time to diversifying tourism products (Lane, 1994).

\subsection{The Development of Tourism Village}

The orientation of tourism development needs to put the facts of environmentally alternative tourism development as the main consideration in developing capacity and capability in society (Beeton, 2006). It can improve the service as well as realize the central role of the community in tourism development activities in accordance with the expectations and capabilities possessed.

In Indonesia, the development of tourism village is more facilitated by the state, while the people tend to be passive. As a result, local capacity in responding to state-sponsored innovations through the development of tourism villages still faces a number of crucial issues (Damanik , 2009). The involvement of villagers in the development of tourism village becomes crucial, because from them, we will know and understand the extent of the potential of the region. In addition, this engagement is vital to gaining support and ensuring that what is to be gained is related to the needs and benefits of the local people. Finally, the role of citizens in the development of tourism is urgent to be developed and placed as an integrated part. Community participation is not primarily a process of strengthening the capacity of local communities, but it can act as a mechanism to increase the empowerment of citizens to engage in joint development. Some forms of community involvement are the provision of accommodation facilities in the form of homestay, the provision of tourist consumption needs, tour guides, the provision of local transportation, art performances, and others.

In the context of tourism development, community participation is important to be encouraged in order to distribute the benefits of tourism activities directly to the community. The spirit of decentralization and the full granting of authority for citizens to manage tourism in their areas is essential for the realization of communitybased tourism. In the process of economic development in the rural areas the citizens should not only be the object, but as subjects in determining the direction of the development of society. The essence of community participation is how to increase bargaining power the community itself, so that its position becomes balanced with the government or investors. It also serves as a power to control the policies taken by the government, resulting in synergies between local resources, the political power of the government, and outside resources or investors. In accordance with the nature of tourist villages which should be initiated internally and independently by local communities this means that the government, both central and local levels only as a facilitator. The process of growing and developing a tourist village will depend on the community itself.

\subsection{Tourism Awareness and Pokdarwis in the Development of Tourism Destination}

Tourism needs a variety of empowerment efforts, so that people can play a more active and optimal, at the same time receive positive benefits from development activities undertaken to improve welfare. Community empowerment in the context of tourism development can be defined as: "Strengthening and capacity building efforts, roles and initiatives of the community as one of the stakeholders, to be able to participate and play an active role as subject or actor or beneficiary in sustainable tourism development" (Directorate of Community Empowerment, 2010)

The definition affirms the important position of the community in development activities, i.e. the community as the subject or the agent of development; and communities as beneficiaries of development. The community as the subject or the developer means that the community becomes an important player, who must be actively involved in the planning and developing process of tourism, together with other relevant stakeholders from both government and private sector. In its function as subjects or actors of the community have a role and responsibility to jointly encourage successful development of tourism in its territory. The community as beneficiaries means that the community is expected to obtain significant economic value from the development of tourism activities to improve the quality of life and social welfare of the people concerned.

Within the framework of tourism development, one of the fundamental aspects to the success of tourism development is the creation of a conducive environment and atmosphere that encourages the growth and 
development of tourism activities in a place. The climate or conducive environment is mainly associated with the realization of "Tourism Awareness" and "Sapta Pesona" which is developed consistently among the people who live around the tourism destinations. Tourism Awareness in this case is described as a form of public awareness to play an active role in the following 2 (two) things, i.e: a) Communities realize the role and responsibility as a host is good for guests or tourists who visit to realize conducive environment and atmosphere as stated in the slogan of Sapta Pesona; b) The public realize the right and need to be a tourism stakeholders..

SAPTA PESONA, as mentioned above are: "7 (seven) elements of charm that must be realized for the creation of a conducive environment and ideal for the development of tourism activities in a place that encourages the growing interest of tourists to visit". The seven elements of Sapta Pesona mentioned above are: 1) Safe; 2) Orderly; 3) Clean; 4) Cool; 5) Beautiful; 6) Friendly and 7) Memorable. The realization of the seven elements of Sapta Pesona in the development of tourism in the region will lead to: 1) Increase the interest of tourist visits to destinations; 2) The growth of prospective tourism business climate and 3) Increase employment and income opportunities, as well as multi economic tourism impact for the community.

There are four general strategies in marketing or encouraging a city to be more attractive to tourists, entrepreneurs or investors to a particular city or region (Kotler, 2002) by: 1) Image marketing: the uniqueness and goodness of the image . Often supported by slogans; 2) Attraction marketing: attractions or natural beauty, buildings and historic sites, parks and landscapes, convention and exhibition centers, malls and s upermarkets; 3 ) Infrastructure marketing: infrastructure as a supporter of environmental attractiveness of life and business environment, including roads, railways, airports, and communication networks and information technology; and 4) People marketing: among other things includes hospitality, heroes or local renowned, competent personnel, entrepreneurship skills and positive comments or responses of the former resident to the market place.

Tourism awareness and "Sapta Pesona" as an important element in support the development of tourism destinations certainly can not be realized automatically without any steps and efforts to pioneer, grow, develop and implement consistently in tourism destinations. Therefore, community participation is needed to be actively promoted in developing Tourism awareness and Sapta Pesona together with other relevant stakeholders. In this case the Pokdarwis or the tourism drive group as an informal institutional establishment formed by members of the community (especially those concerned with developing tourism in the region), is one of the stakeholder elements in the community that has important linkages and roles in developing and realize the tourism awareness and Sapta Pesonoin the area.

\subsection{Information Technology Utilization}

Web technology is one of the information technology that can be utilized to support the effectiveness and efficiency of daily business activities, business actors in the field of tourism.. Web 3.0 also allows to be used in support of tourism business transactions in addition to providing tourism information. Based on Law $11 / 2008$ about Information and Electronic Transactions guarantees the legality of electronic transactions, which are currently inextricably linked to the global tourism business. This indicates that information technology plays a role to support the process of public service including tourism. The website has been proven to be used as a media promotion of tourism products and transactions of booking and payment.

However, the incorrect use of technology will make tourism business losses. Pearlson and Saunders says "Although I can facilitate the movement and exchange of information, it is inappropriate for a given operating environment that can actually inhibit and confuse that same exchange" (Pearlson \& Saunders, 2009). From this statement can be concluded that if the development of an information system in all areas, including in the field of tourism, which is done not in accordance with the needs and also do not pay attention to changes in the system environment, the cost incurred will not be comparable with the results obtained, either directly or indirectly. Therefore, the use of web technology in the field of tourism, should pay attention to data and information needs for tourism business stakeholders, as implied in Goverment Regulation 47 /1997 about The National Spatial Plan, the characteristics of the necessary tourism data and information, and the desirable characteristic of services included in supporting tourism promotion.

\section{Method}

This research is a case study on Pokdarwis in Four Villages of Pesanggrahan, Junrejo, Dadaprejo and Tulungrejo in Batu City. Analytical techniques used in this study is descriptive analysis. This data analysis is done by understanding and compiling data that has been collected systematically based on community response in all four villages

\section{Result and Discussion}

In general, the four villages of Pesanggrahan, Junrejo, Dadaprejo and Tulungrejo have interesting tourism potential (Table 1). But unfortunately the potential has not been optimally revealed. People who are able to produce their own products tend to work alone to sell their products. Whereas if people work together to promote 
their village, it will be a lot of tourists come to the village. One of the participating community's exemple is community around the Depok Parangtritis beach in Yogyakarta (Nawawi, 2013). The communities jointly set up "Koperasi" to manage and recycle garbage around the beach. It is beneficial for the environment and provide additional income for communities around the beach. If the beach in a clean condition, it will attract more tourists come to the be

Pokdarwis was formed to mobilize community participation to jointly develop tourism potential in the village. But unfortunately, the role of each Pokdarwis in 3 villages is not optimal yet. Only one village is Tulungrejo Village whose Pokdarwis activities are visible. The community does not yet have an awareness of the importance and benefits of developing tourism activities in the village. Hidayatullah finds that actually one of the leader of Pokdarwis in Pesanggrahan Village is actually quite active and creative trying to develop his village. One of his ideas is to develop the area of Mount Panderman to be like the area of Mount Bromo. If people around Mount Panderman want to work together to provide horses and "motor trail" to facilitate tourists climbing Mount Panderman,it will attract more tourist. But unfortunately, this creative idea is still difficult to accept by society (Hidayatullah, Kusdyah, Khouroh, \& Windhyastiti, 2017). In this case, the Goverment of Tourism Department should play an active role in raising public awareness and facilitating the activities of Pokdarwis.

Table 1.Tourism Potential Village

\begin{tabular}{|c|c|c|c|}
\hline No & Village & Hamlet & Tourism Potential \\
\hline \multirow[t]{7}{*}{1} & \multirow[t]{7}{*}{ Pesanggrahan } & Wonosari & Fishing tour and quoting vegetables \\
\hline & & Macari & Religious tourism (the oldest mosque that stood in 1825) \\
\hline & & & $\begin{array}{l}\text { Herbal education tours (tours that offer educational traditional medicine / } \\
\text { beauty products }\end{array}$ \\
\hline & & Srebet Barat & $\begin{array}{l}\text { Religious tourism (Mayangsari Tomb) } \\
\text { Nature tourism Source "Kasinan" (hot water) }\end{array}$ \\
\hline & & $\begin{array}{l}\text { Srebet } \\
\text { Timur }\end{array}$ & $\begin{array}{l}\text { Cultural tourism "Bantengan" } \\
\text { Nature tour jogging track on the slopes of the mount Panderman }\end{array}$ \\
\hline & & Krajan & $\begin{array}{l}\text { Cultural Tour (art studio of Mr. Sunarto) } \\
\text { Cultural Tour (traditional music "campursari" owned by Mr. Jumeneng } \\
\text { songwriter Batu Tourism City) } \\
\text { Historical tour (royal heritage statue) }\end{array}$ \\
\hline & & Toyomerto & $\begin{array}{l}\text { Nature tourism (Mount Panderman) } \\
\text { Dairy cattle tour (biggest milk supplier in Batu City where number of cows } \\
\text { more than the population) } \\
\text { Cultural tourism (source ceremony) }\end{array}$ \\
\hline 2 & Junrejo & Rejoso & Wood craft tour (kitchen appliance) \\
\hline \multirow[t]{2}{*}{3} & \multirow[t]{2}{*}{ Dadaprejo } & Karangploso & Ceramic craft tour \\
\hline & & Areng-areng & $\begin{array}{l}\text { Plant breeding tour } \\
\text { Earthenware tour } \\
\text { Cultural tourism "Jaranan" }\end{array}$ \\
\hline \multirow[t]{4}{*}{4} & \multirow[t]{4}{*}{ Tulungrejo } & Gondang & $\begin{array}{l}\text { Plantation tours (apple picks) } \\
\text { Educational tour (processing of apple chips) }\end{array}$ \\
\hline & & Wonorejo & Waterfall (Coban Talun) \\
\hline & & Junggo & $\begin{array}{l}\text { Religious tourism (Pura Giri Arjuna) } \\
\text { Historical tour (Mr. Dengger's grave) and Villa of Bung Karno (Milky } \\
\text { Way) }\end{array}$ \\
\hline & & Kekep & Cultural arts tour (kuda lumping, pencak silat, reog) \\
\hline
\end{tabular}

Source : Primary Data

Based on the results of data analysis shows that in the three locations of tourist villages, Pokdarwis still has not played an effective role in tourism activities. Only one village is Tulungrejo Village whose Pokdarwis activities are visible. The head of the pokdarwis in Tulungrejo village is quite active and creative in mobilizing the community. Based on tourism villages in Batu City (Hidayatullah, Kusdyah, Windhyastiti, \& Khouroh, 2017), in general Pokdarwis in the three villages faced obstacles in the implementation of activities in terms of: 1) Pokdarwis members still lacked awareness about the importance and benefits of increasing tourism activities in the region; 2) Pokdarwis members still due independently marketing and promoting their personal business, not their region; and 3) The Government of Tourism Department does not coordinate and assist them intensively. These three things, hampered the development of tourist villages. That results are in accordance with the opinion that lack of coordination and cooperation between departments of government can be very damaging to not only the quality of the tourism product, but also to the efectiveness of participatory tourism develoment approach. On 
the other hand, lack of roles of agencies, overlap in responsibilities of government departments and little accountability between them make the most needed coordination for participatory tourism development approach less possible. In brief, a participatory tourism development strategy will invite more actors to play roles in the tourism development process, and thus increase the need for interaction among agencies. That is in accordance with opinion of Timothy and Tosun. Timothy says that operational barriers include centralisation of public administrations systems including tourism, lack o f coordination among private and various public bodies responsible for tourism development. (Timothy, 1998). Then Tosun says that any lack of coordination may frustrate potential opportunities for the community to involve itself in tourism development (Tosun, 2000)

In fact in these three villages each has excellent potential that can be developed. Therefore, to improve the role of Pokdarwis it is suggest that the goverment must empower Pokdarwis trough : 1) Conduct socialization and training to open the the community mind about the importance and benefits of tourism activities development in the region; 2) Help choose a reliable leader; and 3) Conduct intensive coordination and assistance. In general it can be concluded that the existence of Pokdarwis needs to be supported and nurtured continuously so that it can play a more effective role in participating in mobilizing public participation in creating environment and atmosphere conducive to the growth and development of tourism activities around tourism destinations. In addition it also needs the introduction of information technology for Pokdarwis to promote the potential of their village. The model of tourism village development in this research as follows :

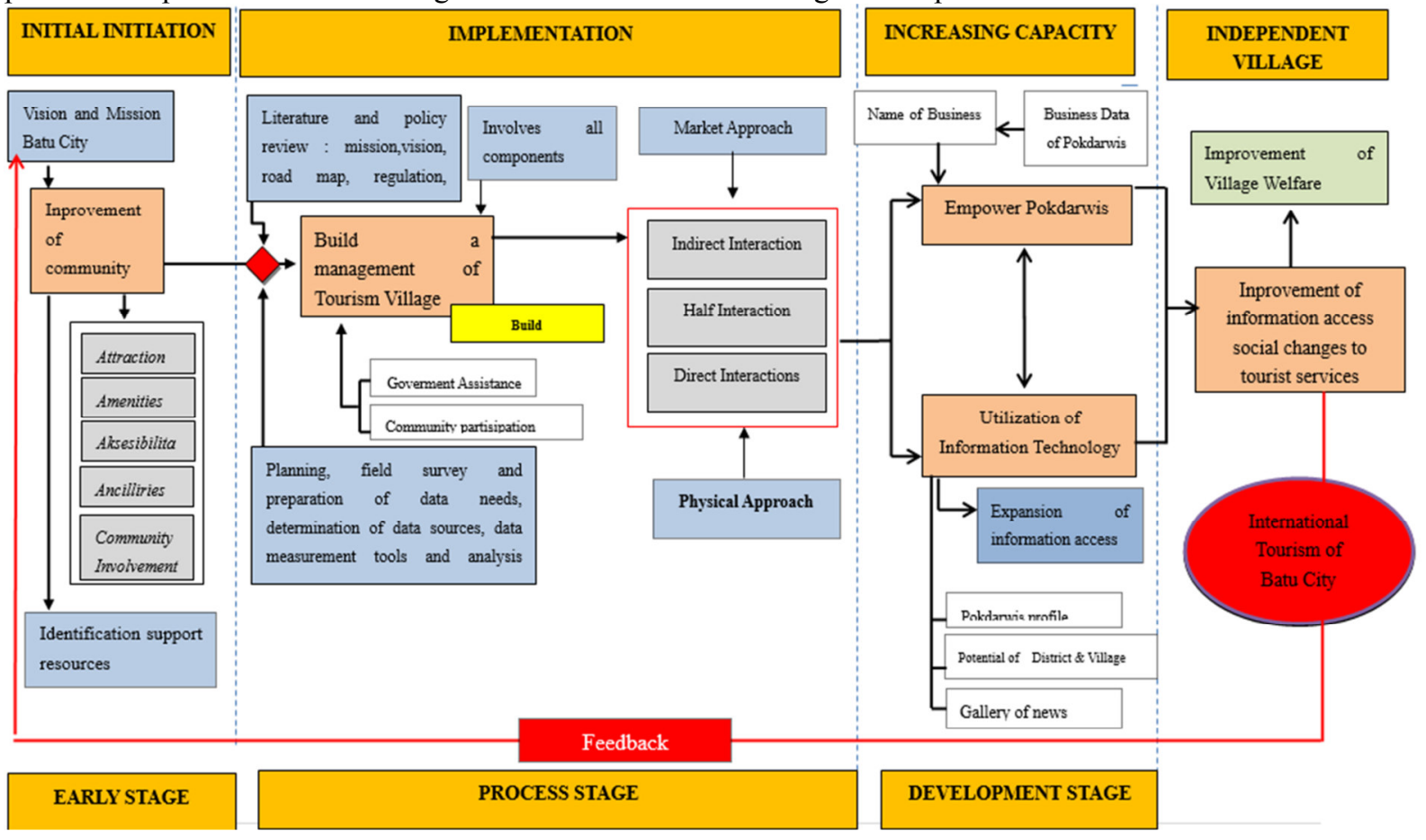

\section{Conclusion}

Based on that model, the development of tourist village towards independent village can be done through 3 stages: 1) Early stage: improvement of community awareness and identification of resources; 2) Process stage : build a management of tourism village (create pokdarwis institution with government assistance) and ; 3) Developmnet stage : increasing capacity through Pokdarwis empowerment and information technology utilization

\section{References}

Bahaire, T., \& Elliot-White, M. (1999). Community Participation In Tourism Planning And Development In The Historic City Of York. Tourims, 243-276.

Beeton, S. (2006). Community Development Through Tourism. Australian: Landlinks Press.

Damanik , J. (2009). Isu-Isu Krusial Dalam Pengelolaan Desa Wisata Dewasa Ini. Jurnal Kepariwisataan Indonesia, 131-133.

D'amore, L. J. (1983). Guideline To Planning In Harmoni With The Host Community In Tourism In Canada. Canada: Victoria University.

Directorate Of Community Empowerment. (2010). Community Empowerment. Indonesian: Directorate Of Community Empowerment.

Getz, D., \& Jamal, T. (1994). The Environment-Community Symbiosis: A Case For Collaborative Tourism 
Planning. Journal Of Sustainable Tourism, 152-173.

Gunn, C. (1972). Vacationscape: Designing Tourism Regions. New York: Van Norstrand Reinhold.

Hidayatullah, S., Kusdyah, I., Khouroh, U., \& Windhyastiti, I. (2017). The Effectivity Of "Pokdarwis" Role On Successfully Marketing Of Tourism Village Towards "Mega Tourism : Batu City For The World". Proceeding Of International Conference Sustainable Development Goals 2030 : Challenges And Its Solutions. Malang, Indonesian: University Of Merdeka Malang.

Intyaswono, S., Yulianto, E., \& Mawardi, K. M. (2016). Peran Strategi City Branding Kota Batu Dalam Trend Peningkatan Kunjungan Wisatawan Mancanegara (Studi Pada Dinas Pariwisata Dan Kebudayaan Kota Batu). Jurnal Administrasi Bisnis, 65-73.

Kotler, P. (2002). Manajemen Pemasaran. Indonesian: Prehallindo.

Lane, B. (1994). What Is Rural Tourism. Journal Of Sustainable Tourism, 7-21.

Ministry Of Culture And Tourism. (2001). Criteria Village Tourims. Indonesian: Ministry Of Culture And Tourism.

Murphy, P. E. (1985). Tourism: A Community Approach. New York: Methuen.

Muzha, V. K., Ribawanto, H., \& Hadi, M. (2013). Pengembangan Agrowisata Dengan Pendekatan Community Based Tourism (Studi Pada Dinas Pariwisata Kota Batu Dan Kusuma Agrowisata Batu). Jurnal Adminstrasi Publik, 135-141.

Nawawi, A. (2013). Partisipasi Masyarakat Dalam Pengelolaan Wisata Pantai Depok Di Desa Kretek Parangtritis. Jurnal Nasional Pariwisata, 103-109.

Pearlson, K., \& Saunders, C. (2009). Strategic Managemnt Of Information System. New Jersey: John Willey \& Sons.

Pinel, D. P. (1998). A Community-Based Tourism Planning Process Model: Kyuquot Sound Area. Canada: University Of Guleph.

Timothy, D. (1998). Cooperative Tourism Planning In A Developing Destination. Journal Of Sustanable Tourism, 52-68.

Tosun, C. (2000). Limits To Community Participation In The Tourism Development Process In Developing Countries. Tourism Management, 613-633.

Wearing, S., \& Donald, M. (2002). The Development Of Community Based Tourism: Re-Thinking The Relationship Between Tour Operators And Development Agents As Intermediaries In Rural And Isolated Area Communities. Journal Of Sustainable Tourism, 191-206. 